\title{
Steciana
}

\section{THE OCCURRENCE OF ATRIPLEX LITTORALIS L. IN POLAND}

\author{
Halina Ratyńska, Barbara Waldon-Rudzionek, EWa Wachowiak
}

H. Ratyńska, B. Waldon-Rudzionek, E. Wachowiak, Department of Botany, Institute of Environmental Biology, Kazimierz Wielki University, Ossolińskich 12, 85-093 Bydgoszcz, Poland, e-mail: harat@ukw. edu.pl,waldon@ukw.edu.pl

(Received: June 20, 2016. Accepted: August 4, 2016)

\begin{abstract}
Aвstract. The Atriplex littoralis L. is a rare and endangered species in Poland and many other countries in Europe. In Poland it is mainly found on the west coast and also rarely in central parts. It has been seen in Puck Bay and the Gulf of Gdańsk as well as in Hel Peninsula. The grassleaf orache is a halophyte, terophyte and a sunlight-loving plant. Data shows that apart from on the coast, this species may also appear in inland areas, for example on ruderal habitats such as roadsides. The results of our observations confirm the presence of the species on beaches and rocky bank reinforcement, with accumulation of annual vegetation in the Hel Peninsula and Puck Bay. Five sites, where Atriplex littoralis specimens occur have been found. In each site 1 to 15 specimens where found, in total 31. Five phytosociological relevés were made within the floristically poor patches of Matricario maritimae-Atriplicetum littoralis (Christiansen 1933) R.Tx. 1950. This association represents the protected type of habitat: Annual vegetation of drift lines (1210).
\end{abstract}

Key words: Atriplex littoralis, Hel Peninsula, Puck Bay, distribution of species, characteristics of vegetation

\section{INTRODUCTION}

Atriplex littoralis is a species critically endangered in Poland (CR) and extensively characterised in the Polish red book of plants (Kaźmierczakowa et al. 2014). It is also on the Polish red list under category E (disappearing - critically endangered) - ZARZYCKI \& SzELĄG (2006), as well as on regional red lists including Western Pomerania and Gdańsk Pomerania (Markowski \& Buliński 2004, OlsZewski \& Markowski 2006) under categories V and VU - vulnerable. Due to its biology (therophyte) and occupied habitat (almost exclusively in a direct vicinity of the sea, within winter wave range), the plant appears quite ephemerally and its positions are impermanent. It was reported from our country primarily from the west coast (Piotrowska \& Celíśsi 1965, PiotrowSKA 1966a, Misiewicz 1976), occasionally found in the middle part (Piotrowska 1966b), and more often at the Bay of Puck and the Bay of Gdańsk (AвRomert et al. 1898-1940, Schwarz 1967, Piotrowska 1980, 1988). Positions in the interior of the country are considered uncertain (PiotrowsKa 1988, 2001).

In recent years, Atriplex littoralis was observed along the Polish coast by Piotrowska (2003),
Afranowicz (2009), as well as Markowski \& OlszewSKI (2014). During the geobotanical diagnoses conducted on the Hel Peninsula and in the Bay of Puck in 2012, fairly numerous positions of this species were highlighted. It has inspired to carry out more detailed research and literature studies. This article aims to deepen the knowledge about the distribution of grassleaf orache in our country, conditions of its occurrence, and phytocoenotic relationships. Results of the own research were related to data from other European regions.

\section{MATERIAL AND METHODS}

The field studies were carried out in the growing season (August-September) in 2012 on the Hel Peninsula and the Bay of Puck. Current position Atriplex littoralis were mapped and identified individuals were counted. Using commonly accepted Braun-Blanquet method, five phytosociological records were made and compared with available materials from the region of Poland (Table 1).

Plant names and membership to geographical and historical groups and forms of life is in accordance to RUtKowski (2004). Syntaxonomic description and 
Table 1. Floristic composition and structure of communities with the participation of Atriplex littoralis (Matricario maritimae-Atriplicetum littoralis?) in Poland

\begin{tabular}{|c|c|c|c|c|c|c|c|c|c|c|c|}
\hline Succesive number of relevé & 1 & 2 & 3 & 4 & 5 & 6 & 7 & 8 & 9 & 10 & 11 \\
\hline Number of relevé in the field & 5 & 86 & 11 & 84 & 72 & 41 & 15 & 18 & 18 & 18 & 26 \\
\hline Date & 31.08 .12 & 13.09 .12 & 31.08 .12 & 13.09.12 & 12.09.12 & 25.07 .94 & 1.07 .03 & 1.07 .03 & 1.07 .03 & 1.07 .03 & 1.07 .03 \\
\hline Authors & 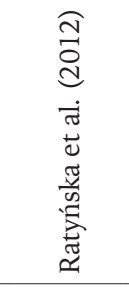 & 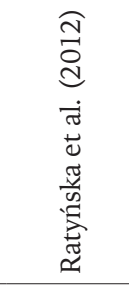 & 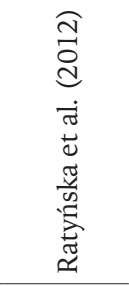 & 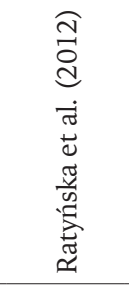 & 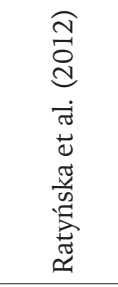 & 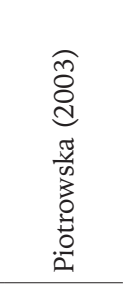 & 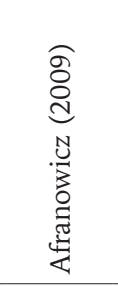 & 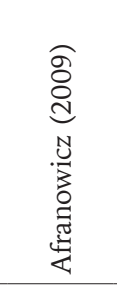 & 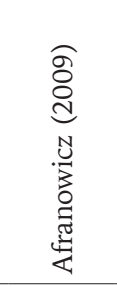 & 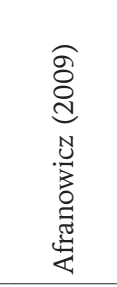 & 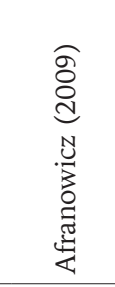 \\
\hline Location & 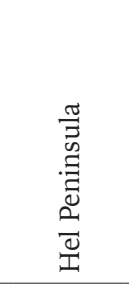 & 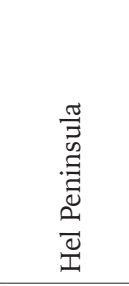 & 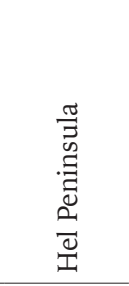 & 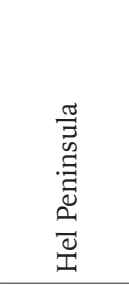 & 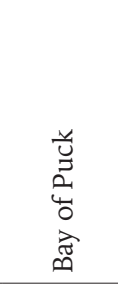 & $\overbrace{\vec{s}}^{u}$ & 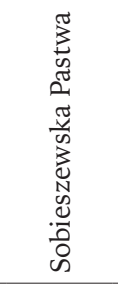 & 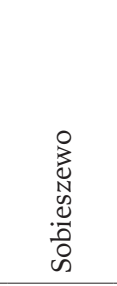 & 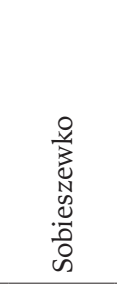 & 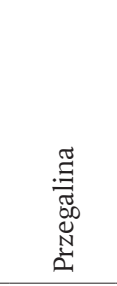 & 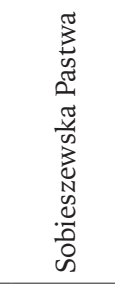 \\
\hline Tree layer cover (\%) & - & - & - & - & - & 5 & - & - & - & - & - \\
\hline Shrub layer cover (\%) & - & - & - & - & - & 1 & - & - & - & - & - \\
\hline Herb layer cover (\%) & 5 & 25 & 5 & 15 & 15 & 75 & 70 & 100 & 70 & 80 & 60 \\
\hline Exposure & $\mathrm{N}$ & $\mathrm{N}$ & $\mathrm{N}$ & $\mathrm{N}$ & $\mathrm{N}$ & - & - & - & - & - & - \\
\hline Inclination $\left(^{\circ}\right)$ & minimal & minimal & minimal & 25 & $15-20$ & - & - & - & - & - & - \\
\hline Area of relevé $\left(\mathrm{m}^{2}\right)$ & 9 & 7 & 10 & 5 & 3 & 6 & 30 & 25 & 25 & 25 & 20 \\
\hline Number of species & 10 & 15 & 9 & 9 & 13 & 11 & 11 & 25 & 15 & 14 & 8 \\
\hline \multicolumn{12}{|l|}{ I. Ch. Cakiletea maritimae } \\
\hline Atriplex littoralis & + & 1 & + & + & 2 & 1 & + & + & 1 & + & + \\
\hline Atriplex prostrata subsp. prostrata & & & $\mathrm{r}$ & + & + & 2 & & & & 2 & \\
\hline Cakile maritima subsp. baltica & & 2 & $\mathrm{r}$ & 2 & & 4 & & & & & \\
\hline Salsola kali subsp. kali & + & & & & & + & & & & & \\
\hline \multicolumn{12}{|l|}{ II. Ch. Ammophiletea } \\
\hline Honckenya peploides & & + & & & & & & & & & \\
\hline $\begin{array}{l}\text { Lathyrus japonicus subsp. mariti- } \\
\text { mus }\end{array}$ & & 1 & + & $\mathrm{r}$ & & & & & & & \\
\hline Ammophila arenaria & & & + & + & & & & & & & \\
\hline Leymus arenarius & & 1 & & & & 2 & & & & & \\
\hline Petasites spurius & & & & & & 1 & & & & & \\
\hline \multicolumn{12}{|l|}{ III. Ch. Koelerio-Corynephoretea } \\
\hline Hypochoeris radicata & + & & & & & & & & & & \\
\hline Viola tricolor subsp. curtisii & + & & & & & & & & & & \\
\hline Jasione montana var. littoralis & + & $\mathrm{r}$ & & & & & & & & & \\
\hline Corynephorus canescens & + & + & & & & & & & & & \\
\hline Artemisia campestris subsp. sericea & + & 1 & + & $\mathrm{r}$ & & & & & & & \\
\hline Festuca rubra subsp. arenaria & & 1 & 1 & & & & & & & & \\
\hline Hieracium umbellatum var. dunense & & + & & & & & & & & & \\
\hline \multicolumn{12}{|l|}{ IV. Ch. Molinio-Arrhenatheretea } \\
\hline Achillea millefolium & & & & & + & & & & & & \\
\hline Poa palustris & & & & & + & & & & & & \\
\hline Taraxacum officinale & + & + & & $\mathrm{r}$ & 1 & & & + & & & \\
\hline Potentilla anserina & & & & & & + & & + & + & & \\
\hline Agrostis stolonifera & & & & & & & 2 & 3 & 2 & + & + \\
\hline Juncus compressus & & & & & & & & 1 & + & & \\
\hline Vicia cracca & & & & & & & & + & & & \\
\hline Agrostis gigantea & & & & & & & & & 1 & & \\
\hline Scirpus sylvaticus & & & & & & & & & & & 2 \\
\hline
\end{tabular}




\begin{tabular}{|c|c|c|c|c|c|c|c|c|c|c|c|}
\hline Succesive number of relevé & 1 & 2 & 3 & 4 & 5 & 6 & 7 & 8 & 9 & 10 & 11 \\
\hline \multicolumn{12}{|l|}{ V. Ch. Artemisietea vulgaris } \\
\hline Artemisia vulgaris & & & & & + & & & & & & \\
\hline Calystegia sepium & & & & & 1 & & & 2 & + & & \\
\hline Cirsium arvense & & & & & + & + & & 1 & + & + & \\
\hline Elymus repens & & & & & & + & & + & + & & \\
\hline Galium aparine & & & & & & & & + & & & \\
\hline $\begin{array}{l}\text { Angelica archangelica subsp. } \\
\text { litoralis }\end{array}$ & & & & & & & & + & & & \\
\hline Galeopsis pubescens & & & & & & & & + & & & \\
\hline Sonchus palustris & & & & & & & & + & & & \\
\hline \multicolumn{12}{|l|}{ VI. Ch. Stellarietea mediae } \\
\hline Senecio vulgaris & + & & & & & & & & & & \\
\hline Conyza canadensis & & + & & & & & & & & & \\
\hline Stellaria media & & + & & & & & & & & & \\
\hline Capsella bursa-pastoris & & & + & & & & & & & & \\
\hline Atriplex patula & & & & & + & & & & & & \\
\hline Lactuca serriola & & & & & + & & & & & & \\
\hline Sonchus arvensis & & & & & + & & & & & + & \\
\hline Sonchus oleraceus & & & & & & & & & + & + & \\
\hline \multicolumn{12}{|c|}{ VII. Ch. Juncetea maritimi (Asteretea tripolium) } \\
\hline Aster tripolium & & & & & & & + & & & + & + \\
\hline Plantago winteri & & & & & & & & + & 1 & + & \\
\hline Triglochin maritima & & & & & & & & + & & & + \\
\hline Glaux maritima & & & & & & & & + & & & \\
\hline \multicolumn{12}{|l|}{ VIII. Ch. Phragmitetea } \\
\hline Scirpus lacustris subsp. lacustris & & & & & & & + & & & & \\
\hline Hippuris vulgaris & & & & & & & + & 1 & + & & \\
\hline Eleocharis palustris & & & & & & & 1 & + & & & + \\
\hline Phragmites australis & & & & & & & + & 4 & 3 & 4 & + \\
\hline $\begin{array}{l}\text { Scirpus lacustris subsp. taber- } \\
\text { naemontani }\end{array}$ & & & & & & & + & & & + & 3 \\
\hline Rumex hydrolapathum & & & & & & & + & & & + & \\
\hline Bulboschoenus maritimus & & & & & & & + & & & 1 & \\
\hline Typha angustifolia & & & & & & & 3 & & & & \\
\hline Galium palustre & & & & & & & & + & & & \\
\hline Ranunculus lingua & & & & & & & & + & & & \\
\hline Carex vulpina & & & & & & & & 1 & + & & \\
\hline Iris pseudacorus & & & & & & & & + & + & & \\
\hline \multicolumn{12}{|l|}{ IX. Ch. Bidentetea tripartitae } \\
\hline Polygonum mite & & & & & & & & & & + & \\
\hline \multicolumn{12}{|l|}{ X. Ch. Isoëto-Nanojuncetea } \\
\hline Juncus bufonius & & & & & & & & & + & & \\
\hline \multicolumn{12}{|l|}{ XI. Others } \\
\hline Pinus sylvestris c & + & + & + & $\mathrm{r}$ & & & & & & & \\
\hline Alnus glutinosa a/c & & + & & & & 1 & & & & & \\
\hline Populus tremula c & & & & + & & & & & & & \\
\hline Poa аппиа & & & & & + & & & & & & \\
\hline Rubus sp. c & & & & & + & & & & & & \\
\hline Acer pseudoplatanus b & & & & & & + & & & & & \\
\hline Polygonum amphibium $\mathrm{f}$. terrestre & & & & & & & & + & & & \\
\hline Carex pairae & & & & & & & & + & & & \\
\hline Rumex sanguineus & & & & & & & & & & + & \\
\hline
\end{tabular}


the assessment of prevalence and risks of the community was performed after RATYŃsKA et al. (2010). Membership in protected habitat types is consistent with Announcement of Ministry of Environment dated October 30, 2014 (OBwieszCZENIE... 2014).

With regard to the phytosociological records, the principal component analysis (PCA) was carried out using MVSP software (KovaCH 2002).

A rich literature cited in the rest of the work was used to characterise the species and its communities.

\section{RESULTS AND DISCUSSION}

\section{GENERAL CHARACTERISTICS OF THE SPECIES}

Atriplex littoralis L. has a continental-littoral range. In Europe, it grows along of southern and north-western seashores, and occasionally occurs in inland ruderal habitats (Meusel et al. 1965, Maglocký \& FeraKOVÁ 1993, ČĚ̌́VSKÝ et al. 1999, PIOTROWSKA 2001). It is also reported from the sea coast and inland salt flats of Asia and North Africa (MARKowski \& OlszewSKI 2014). Some interesting details can be found in publications by Badmin (1979), Feltwell \& Philp (1980), ScotT \& DAVISON (1982), about its presence on roadsides in the United Kingdom (Kent) and other ruderal areas (GUSTAFSSON 2001), which indicates a considerable apophytic ability of the species and ability to colonize even the eminently anthropogenic habitats. Relatively fertile ground and salinity are the conditions for its presence.

Grassleaf orache is an annual therophyte, the development optimum of which falls on summer and early autumn. It reaches a height of $70 \mathrm{~cm}$, rarely higher. Frequently, a single stem with numerous side, upwards raised branches grows, giving the plant a rare Christmas tree conformation.

According to the ecological indicator numbers (ZARZYCKI et al. 2002), it is rare species, and its dy- namic trends in recent decades indicate a large decrease in the number of positions (from 40 reported to 4 confirmed - MarkowsKi \& Olszewski 2014), which finds a confirmation in listing in Polish red book (ZARZYCKI et al. 2014) and on Polish red list (ZARZYCKI \& SZELĄG 2006). It has the status of endangered species also in Czech Republic (ČEŘOvsKÝ et al. 1999, Holub \& ProcházKa 2000) and Slovakia (MaglockÝ \& Feraková 1993). In the UK, it is under legal protection. The plant is very heliophilous, occurring exclusively in open habitats under moderately warm climatic conditions, typical of the early stages of succession (Hill 2004, Hoffmann et al. 2005, Piesschaert et al. 2005, Erfanzadeh et al. 2009). It is considered as a sub-Atlantic character species (MeUSEL et al. 1965), which is indicated by its distribution through Europe (FUKAREK et al. 1967) and concentration of positions at the Western coast and their lack at the Eastern coastline of our country (AвRомеIт et al. 1898-1940, Piotrowska \& Celiński 1965, PioTROWSKA 1966a, b, 1980, 1988, 2001, SCHWARZ 1967, MisiEwicz 1976), although it has been observed along the coast of Gulf of Bothnia (Hultén \& Fries 1986), and WojTERSKA reported it in 2013 on Latvian coast (oral information).

The species grows on fresh, moderately poor, mineral-humus, abundant in nitrogen compounds, alkaline - of a $\mathrm{pH}$ above 7 , soils. In the light of current recognition, it was found out that it can also settle the dry, easily permeable, sandy soils, which perhaps is associated with extreme positions of the species. Grassleaf orache is considered halophytic (ZARZYCKI et al. 2002), which confirms its distribution - almost exclusively related the coast.

Polish positions of Atriplex littoralis are reported from beaches; the species is developed at the base of cliffs, in gaps between rocks of the coastal reinforcements, at fences protecting the dunes, in the reeds and saline spots, where vegetation was destroyed

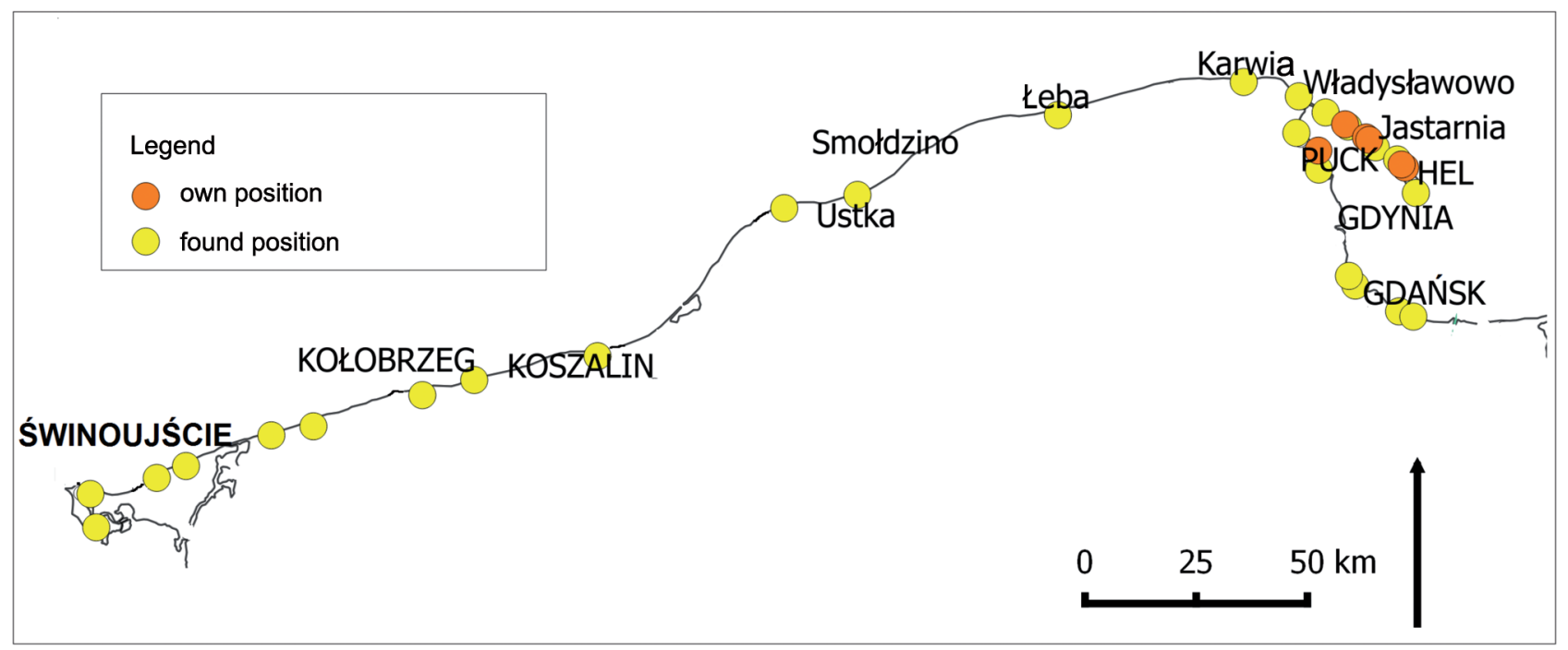

Fig. 1. Distribution of Atriplex littoralis positions along the Baltic Sea coastline of Poland 
(Рiotrowska 2001). These are the places where wash margin is brought by the winter waves or garbage thrown by the people are accumulated.

Observations made by Piotrowska (1966a) indicate that the species appears very casually. In some years, it can be very rare, while in others numerous. PiotrowsKa (1966b) associates it indirectly with the direction and strength of winds and directly with the storm wave bringing larger amounts of wash margin and seeds in winter to a beach.

Five positions of Atriplex littoralis were found during the own recognition (Fig. 1). There were from 1 to 15 individuals of grassleaf orache, in total 31. For comparison, MARKOWSKI \& OlszeWsKi (2014) reported that from single to about 40 individual were recorded in studied populations.

\section{SYNTAXONOMY}

The phytosociological membership of Atriplex littoralis along with the community description is as follows:

Cl. Cakiletea maritimae R.Tx. et Preising in R.Tx. 1950

O. Cakiletalia maritimae R.Tx. in Oberd. 1949 ex R.Tx. 1950 (Syn.: Atriplicetalia littoralis Sissingh in Westhoff et al. 1946)

All. Atriplicion littoralis Nordhagen 1940 (Syn.: Atriplicion littoralis (Nordhagen 1940) R.Tx. 1950, Cakilion maritimae Pignatti 1954 ex Pass. 1978)

Ass. Matricario maritimae-Atriplicetum littoralis (Christiansen 1933) R.Tx. 1950 (Syn.: Atriplicetum littoralis sensu Christiansen 1933, Libbert 1940, Nordhagen 1940 p.p. non Feekes 1936 et div. auct. nom. ambig.)

Phytosociologically, patches of Matricario maritimae-Atriplicetum littoralis were very rarely documented. Piotrowska \& Celiński (1965), who presented a table illustrating the distribution of the most important species of the community on Wolin island, as the first ones signaled its occurrence in our country. Cited authors believe that the community in Poland develops only in fragments. Richer, more developed phytocoenoses were found on the south-eastern Uznam island. In addition to many of the taxa with Chenopodiaceae - from Atriplex and Chenopodium genera, there were present the saline soil and ruderal plants in patches.

Table 1 summarizes the phytosociological records involving Atriplex littoralis made by the authors (1-5) and retrieved from Polish Vegetation Database - SynBiotSilesiae - EU-PL-001: Piotrowska (2003) record 6 and Afranowicz (2009) - records 7-11. Community, usually representing the early stages of succession, is floristically poor and has a very heterogeneous composition, which is largely due to the diverse habitats, it develops on. The table lists 68 taxa, and from 8 to 25 on individual records with average of
14. Grassleaf orache usually occurs with covering of a few, while sometimes dozen or so percent.

It was observed in 2012 that the patches involving Atriplex littoralis colonized more or less inclined places (up to $30^{\circ}$ ) with a northern exposure. These are the edges of the beach at wicker fences stabilizing sand dunes as well as stones strengthening the shore, where wash margin thrown by the storm waves is accumulated. The surface of patches is small - not exceeding $10 \mathrm{~m}^{2}$. All lists recorded 33 taxa, and each record from 9 to 15, with 11 on average. The community is a single-layer and the coverage by herbaceous plants varies from 5 to $25 \%$. The highest levels of stability are shown by Atriplex littoralis, Artemisia campestris subsp. sericea, Taraxacum officinale and Pinus sylvestris. Besides Cakiletea maritimae edifficators, participation of numerous representatives of other nitrophilous plants with Stellarietea mediae and Artemisietea vulgaris is worth mentioning. They are particularly important in the patch developed on thick layer of wash margin accumulated between stones strengthening the Bay shore (record 5). Another group of plants present in all lists, where there was a sandy ground, are psammophilous species initiating the succession on dunes, characteristic of the Ammophiletea and Koelerio-Corynephoretea class.

Record taken by PIOTROWSKA (2003) is of a similar character; it can be classified as Salsolo-Cakiletum balticae Pass. G. et Pass. H. 1973 community. It is also a pioneering community of seashores from the Atriplicion littoralis association. The more advanced succession process is provided by greater coverage of the plants and originally developed layer of trees and shrubs.

Records 7-11 represent groups developed in wet and saline habitats. All lists contain 39 taxa, and from 8 to 25 in individual records with an average of 15 . They are thus floristically more abundant than those outlined above. Very well-developed herbaceous layer diversified into sub-layers reaches from 60 to $100 \%$ coverage, an average of $76 \%$. Studied patches are characterised by a very high share and coverage of rush species with Phragmitetea and grassland with Molinio-Arrhenatheretea. In addition, they are distinguished by the presence of helophytes with Juncetea maritimi and Agrostis stolonifera. Their floristic composition shows that they can be classified as phytocoenoses of proper rushes: Typhetum angustifoliae, Phragmitetum australis, and Scirpetum maritimi.

The PCA analysis indicates that the first axis explains $28.75 \%$, while the second $21.41 \%$ of the total variability of species occurrence (Fig. 2). It allowed to group the phytosociological records into three categories: lists $1-6,7-11$, and $12-13$, completely different from the others. It is worth noting that record 6 taken by PiотrowsKa (2003) to the most refers to own materials, whereas record 3 from the edges of the Bay of Puck, has an intermediate character 


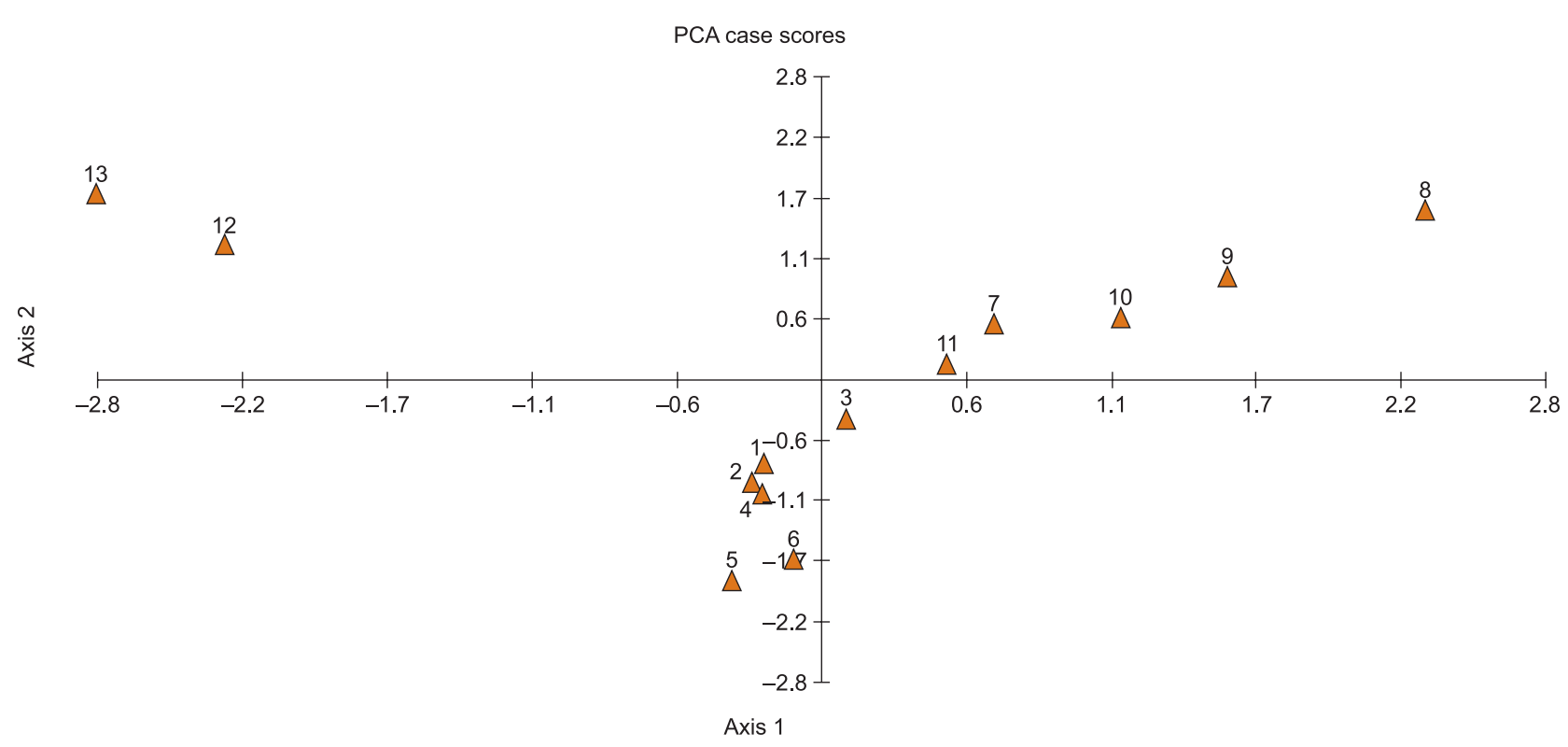

Fig. 2. The principal component analysis (PCA); 1-5 - own materials, 6-13-phytosociological records from Polish Vegetation Database

between other own lists and materials collected by AFRANOWicz (2009).

Very poor materials documenting the presence of Atriplex littoralis in our country do not allow for an unambiguous statement whether the species forms its own group, or it is just the accompanying taxon - a component of various plant communities. Phytosociological records summarized in Table 1 are very heterogeneous and indicate a fairly broad ecological scale of grassleaf orache, which occurs in communities initiating the succession on a white sand dune, in wash margin, in the complex of rushes on salty ground, and in coastal communities of therophytes.

The association has a status of very rare one in our country, perdochoric natural community and category $\mathrm{V}$ - exposed (RATYŃSKA et al. 2010). According to the opinion of some researchers, it is considered extinct in Poland (Matuszkiewicz 2005). Due to the destruction of natural habitats, it is also found in strongly transformed places, such as stone fortified coast, where wash margin is accumulated, and even inland.

Described group of the coastal therophytes is widespread in Europe, at the North Sea and found in the west coast of the Baltic Sea and North Atlantic (Atriplicetum littoralis Libbert 1940, Tüxen 1955, Fukarek 1961), GÉHU (1998). Related community occurring on the coast, sometimes equated with the discussed association is Beto maritimae-Atriplicetum littoralis GéHu 1976. Rivas-Martínez et al. (2001) found it in Portugal and Spain, and GéHu (1998) as well as Duhamel \& Catteau (2010) in France. Participation of Atriplex littoralis with III and IV stability degrees was also reported by SÝKORA (1980) in patches of Agropyretum repentis maritimum Nordhagen 1940,
Atripliceto-Elymetum arenarii (Nordhagen 1940) Dahl \& Hadač 1941, as well as in community Elymus-Agropyron repens Nordhagen 1940.

German DierschKe \& Walbrun (1986) reported six phytosociological records taken in patches of Atriplicetum littoralis Tx. 1937 em. Westh. et Beeft. 1950 community, which can be identified with Matricario maritimae-Atriplicetum littoralis.

Association Matricario maritimae-Atriplicetum littoralis is representative for the protected type of habitat: Annual vegetation of drift lines (1210). Therefore, it is a subject of interest to the Community.

\section{CONCLUSIONS}

Atriplex littoralis is extremely rare and ephemerally occurring species in Poland.

The species was confirmed in Hel Peninsula and Bay of Puck.

In comparison with materials available in the literature, studied patches may be regarded as unusual, extreme positions of the Matricario maritimae-Atriplicetum littoralis association in Poland.

The association, due to the low prevalence and biology of characteristic species, is very poorly recognised in Poland. Analysis of existing materials shows that the majority of phytosociological records can be classified as other communities from different syntaxonomic groups.

Small and continuously decreasing number of Atriplex littoralis positions, intensive management of the seashore, and tourist and recreational pressure make that its communities are extremely exposed to destruction and their protection is very difficult. 


\section{ACKNOWLEDGEMENTS}

The paper has been financially supported by the Polish Ministry of Science and Higher Education through statutory research.

We would like to thank Prof. Zygmunt Kacki, PhD, for sharing the phytosociological photos from Polish Vegetation Database - SynBiotSilesiae - EU-PL-001. Msc Patryk Czortek took part in the fieldwork.

\section{REFERENCES}

Abromeit J., Jentzsch A., Neuchoff W., Stefren H., Vogel G. (1898-1940): Flora von Ost- und Westpreussenherausgegeben. Preussischen Botanisches Verein zu Königsberg, Komissionsverlag Gräfe und Unzer, Königsberg (Pr.).

Afranowicz R. (2009): Vegetation of watercourses and their margines under intense anthropopressure in the Żuławy Wiślane Region (Northern Poland). Roślinność cieków i ich obrzeży w warunkach silnej antropopresji na Żuławach Wiślanych (Północna Polska). Acta Botanica Cassubica, Monographiae 3. FRUG, Gdańsk.

BADMIN J.S. (1979): Recent records of Puccinellia Parl. in E. Kent. Watsonia 12: 390.

Čeňovský J., Feráková V., Holub J. MaglockÝ Š., ProcházKa F. (1999): Červená kniha ohrožených a vzácných druhů rostlin živočichů ČR a SR. 5. Vyšši rostliny. Príroda, Bratislava.

Dierschke H., Walbrun R. (1986): Die vegetation der Fels-Steilküste von Helgoland. Schriften Naturvissenschaftlichen. Vereins für Schleswig-Holstein 56: 35-46.

Duhamel F., Catteau E. (2010): Inventaire des végétations de la région Nord-Pas de Calais. Partie 1. Analyse synsystématique. Evaluation patrimoniale (influence anthropique, raretés, menaces et statuts). Liste des végétations disparues ou menacées. Ouvrage réalisé par le Centre régional de phytosociologie agréé Conservatoire botanique national de Bailleul avec la collaboration du collectif phytosociologique interrégional. Avec le soutien de la Direction régionale de l'environnement, de l'aménagement et du logement du Nord-Pas de Calais, du Conseil régional Nord-Pas de Calais, du Conseil général du Nord, du Conseil général du Pas-de-Calais et de la Ville de Bailleul. Bulletin de la Société botanique de France 63(1): 1-83.

Erfanzadeh R., Garbutt A., Pétillon J., Maelfait J.-P., HofFMAnN M. (2009): Factors affecting the success of early salt-marsh colonizers: seed availability rather than site suitability and dispersal traits. In: R. Erfanzadeh (ed.). Spatio-temporal aspects of early vegetation succession in a recently restored salt-marsh ecosystem: a case study of the IJzer estuary (Belgium). PhD Thesis. Ghent University: $33-52$.
Feltwell J., Philp E. (1980): Natural history of the M20 motorway. Transactions of the Kent Field Club 8: 101-115.

Fukarek F., Kleinke J., Schneider U. (1967): Verbreitungskarten zur Pflanzengeographie Mecklenburgs. Küstenpflanzen 2. Natur Naturschutz Mecklenburg 5: 127-213.

GÉHU J.M. (1998): Schéma synsystématique des principales classes de végétations littorales sédimentaires européennes avec références à d'autres territoires holarctiques. Annali di Botanica 56, 1: $1-8$.

Gustafsson M. (2001): Atriplex L. In: L. Jonsell (ed.). Chenopodiaceae to Fumariaceae. Flora Nordica. Vol. 2. Bergius Foundation, Royal Swedish Academy of Science, Stockholm.

Hill M.O., Preston C.D., Roy D.B. (2004): PLANTATT attributes of british and irish plants: status, size, life history, geography and habitats. Raven Marketing Group, Cambridgeshire.

Hoffmann M., Adam S., Baert L., Bonte D., Chavatte N., Claus R., De Belder W., De Fré B., Degraer S., De Groote D., Dekoninck W., Desender K., Devos K., Engledow H., Grootaert P., Hardies N., Leliaert F., Maelfait J-P., Monbaliu J., Pollet M., Provoost S., Stichelmans E., Toorman E., Van Nieuwenhuyse H., Vercruysse E., Vincx M., WitтовСК J. (2005): Integrated monitoring of nature restoration along ecotones, the example of the Yser Estuary. In: Proceedings 'Dunes and Estuaries 2005' - International Conference on Nature Restoration Practices in European Coastal Habitats, 19-23 September 2005 VLIZ Special Publication 19. J.-L. Herrier, J. Mees, A. Salman, J. Seys, H. Van Nieuwenhuyse, I. Dobbelaere (eds.). Koksijde, Belgium: 191-208.

Holub J., Procházka F. (2000): Red list of vascular plants of the Czech Republic. Preslia 72: 187-230.

HuLtén E., Fries M. (1986): Atlas of North Europaen vascular plants north of the Tropic of Cancer. Vol. 1-3. Koeltz Scientific Books, Königstein.

KaŹmierczaKowa R., Zarzycki K., MireK Z. (2014): Polska czerwona księga roślin. Paprotniki i rośliny kwiatowe. Instytut Ochrony Przyrody PAN, Kraków.

Kovach W.L. (2002): Multivariate Statistical Package. Version 3.1. Pentraeth, Wales, U.K.

MaglockÝ S., Feráková V. (1993): Red list of ferns and flowering plants (Pteridophyta and Spermatophyta) of the flora of Slovakia (the second draft). Biológia (Bratislava) 48/4: 361-385.

MARKowsKi R., BuliŃski M. (2004): Ginące i zagrożone rośliny naczyniowe Pomorza Gdańskiego. Acta Botanica Cassubica, Monographiae 1: 1-75.

Markowski R., Olszewski T. (2014): Atriplex littoralis L. Łoboda nadbrzeżna. In: R. Kaźmierczakowa, K. Zarzycki, Z. Mirek (eds.). Polska czerwona księ- 
ga roślin. Paprotniki i rośliny kwiatowe. Instytut Ochrony Przyrody PAN, Kraków: 104-106.

Matuszkiewicz W. (2005): Przewodnik do oznaczania zbiorowisk roślinnych Polski. Wydawnictwo Naukowe PWN, Warszawa.

Meusel H., JäGer E., Weinert E. (1965): Vergleichende Chorologie der zentraleuropäischen Flora. Bd. 1. Fischer Verlag, Jena.

Misiewicz J. (1976): Flora synantropijna i zbiorowiska ruderalne polskich portów morskich. Wyższa Szkoła Pedagogiczna, Słupsk.

OBWIESZCZENIE Ministra Środowiska $z$ dn. 30 października 2014 r. w sprawie ogłoszenia jednolitego tekstu rozporządzenia Ministra Środowiska w sprawie siedlisk przyrodniczych oraz gatunków będących przedmiotem zainteresowania Wspólnoty, a także kryteriów wyboru obszarów kwalifikujących się do uznania lub wyznaczenia jako obszary Natura 2000 (2014). Dz.U. z dnia 4 grudnia 2014 r., poz. 1713.

Olszewski T., Markowski R. (2006): Uzupełnienie do czerwonej listy roślin naczyniowych Pomorza Gdańskiego. In: T. Olszewski, R. Afranowicz, K. Bociąg (eds). Współczesne kierunki w badaniach botanicznych - tom z okazji 80. urodzin Profesor Hanny Piotrowskiej. Acta Botanica Cassubica 6: 163-172.

Piesschaert F., Mertens J., Huybrechts W., De Rache P. (2005): Early vegetation succession and management options on a brackish sediment dike. Ecological Engineering 25: 349-364.

Piotrowska H. (1966a): Rośliny naczyniowe wysp Wolina i południowo-wschodniego Uznamu. Prace Komisji Biologicznej. Poznańskie Towarzystwo Przyjaciół Nauk, Wydział Matematyczno-Przyrodniczy 30(4).

Piotrowska H. (1966b): Stosunki geobotaniczne wysp Wolina i południowo-wschodniego. Uznamu. Monographiae Botanicae 22.

Piotrowska H. (1980): Anthropogenic changes in the distribution of halophytes on the coastal fringes of the Gulf of Gdańsk. Fragmenta Floristica Geobotanica 26: 279-297.

Piotrowska H. (1988): Atriplex litoralis L. In: A. Jasiewicz (ed.). Materiały do poznania gatunków rzadkich i zagrożonych Polski. Cz. 1. Fragmenta Floristica Geobotanica 33: 305-310.

Piotrowska H. (2001): Atriplex littoralis L. - łoboda nadbrzeżna w Polsce. In: A. Zając, M. Zając (eds). Atlas rozmieszczenia roślin naczyniowych w Pol- sce. Instytut Botaniki Polskiej Akademii Nauk, Kraków.

Piotrowska H. (2003): Zróżnicowanie i dynamika nadmorskich lasów i zarośli w Polsce. Bogucki Wydawnictwo Naukowe, Poznań-Gdańsk.

Piotrowska H., Celiński F. (1965): Zespoły psammofilne wysp Wolina i południowo-wschodniego Uznamu. Badania Fizjograficzne nad Polską Zachodnią 16: 123-170.

RatyŃska H., Wojterska M., Brzeg A. (2010): Multimedialna encyklopedia zbiorowisk roślinnych Polski, Ver. 1.1. Narodowy Fundusz Ochrony Srodowiska i Gospodarki Wodnej, Instytut Edukacyjnych Technologii Informatycznych, Warszawa.

Rivas-Martínez S., Fernández-González F., Loidi J., Lousã M., Penas A. (2001): Syntaxonomical checklist of vascular plant communities of Spain and Portugal to association level. Itinera Geobotanica 14: 5-341 [on-line].

RutKowski L. (2004): Klucz do oznaczania roślin naczyniowych Polski niżowej. Wydawnictwo Naukowe PWN, Warszawa.

SCHWARZ Z. (1967): Badania nad florą synantropijną Gdańska i okolicy. Acta Biologica et Medica Societas Scientarum Gedanensis 11: 363-494.

Scott N.E., Davison A.W. (1982): De-icing salt and the invasion of road verges by maritime plants. Watsonia 14: 41-52.

SÝKORA K. (1980): A revision of the nomenclatural aspects of the Agropyro-Rumicion crispi, Nordhagen 1940. Proceedings of the Koninklijke Nederlandse Akademie van Wetenschappen. Ser. C. Biological and Medical Sciences 83, 4: 355-361.

ZARZYCKI K., SZeląG Z. (2006): Red lost of the vascular plants in Poland. Czerwona lista roślin naczyniowych w Polsce. In: Z. Mirek, K. Zarzycki, W. Wojewoda, Z. Szeląg (eds). Red list of plants and fungi in Poland. Czerwona lista roślin i grzybów Polski. W. Szafer Institute of Botany, Polish Academy of Sciences, Kraków: 9-20.

Zarzycki K., TrZcińsKa-Tacik H., RóŻańSKi W., SzeląG Z., Wotek J., Korzeniak U. (2002): Ecological indicator values of vascular plants of Poland. Ekologiczne liczby wskaźnikowe roślin naczyniowych Polski. W. Szafer. Institute of Botany, Polish Academy of Sciences, Kraków.

For citation: RATYŃSKA H., WALDON-RUDZIONEK B., Wachowiak E. (2016): The occurrence of Atriplex littoralis L. in Poland. Steciana 20(3): 129-136. doi: 10.12657/steciana.020.015 